Brit. F. vener. Dis. (1968), 44, 157.

\title{
ERYTHROMYCIN IN THE TREATMENT OF NON-GONOCOCCAL URETHRITIS*
}

\author{
BY \\ R. R. WILLCOX \\ St. Mary's Hospital, London, W.2
}

Erythromycin was first used by the author in the treatment of non-gonococcal urethritis in 1954. Using relatively small doses of $100 \mathrm{mg}$. four times a day for 6 days in 25 male cases the re-treatment rate within 3 months was 33.3 per cent. of those followed (Willcox, 1954). A further series was then undertaken using $300 \mathrm{mg}$. four times a day for 5 days (Willcox, 1955a, 1955b), which was finally extended to 101 cases when the failure rate proved to be $27 \cdot 1$ per cent. among the 85 patients followed (Willcox, 1955c).

Although these results were similar to those obtained with a combination of a single injection of 1 g. streptomycin together with a course of a sulphonamide, they were not as good as those achieved by the tetracyclines which in the past decade have proved the most successful of the antibiotics used in the therapy of this condition.

Further interest in erythromycin has arisen from more recent developments in mycoplasma research, particularly regarding the so-called $T$. strain which Shepard (1960) found in approximately 70 per cent. of cases of non-gonococcal urethritis, a figure later confirmed by other workers (Csonka, Williams, and Corse, 1966). Although the claims for the T. strain as a probable cause of the condition still remain, they are not entirely conclusive, as these mycoplasmata have been found to be present in 12.6 per cent. of healthy adults (Csonka and others, 1966) and in a higher proportion in some random samples taken from special groups of female patients in whose husbands there was no particular suspicion of nongonococcal urethritis. Moreover other causes of non-gonococcal urethritis also have their champions, as for example, the TRIC virus (Dunlop, Harper, Al Hussaini, Garland, Treharne, Wright, and Jones, 1966), while a diphtheroid bacillus has also been recovered (Furness and Csonka, 1966).

The observation by Shepard, Lunceford, and Baker (1966) that the T. strain of mycoplasma is

* Received for publication August 29, 1967. sensitive in vitro to erythromycin, while the so-called human genital classic mycoplasma (one of the organisms earlier implicated) is not, led to the formulation of an erythromycin inhibition test to distinguish them in the laboratory. This difference in sensitivity has also prompted a further investigation of the effects of erythromycin in the treatment of uncomplicated non-gonococcal urethritis which is the subject of this paper.

\section{Case Material}

106 male patients with uncomplicated non-gonococcal urethritis have been treated with erythromycin. Of these 26 were Negroes-22 from the West Indies, three from West Africa, and one from Guyana. Of the remainder, 61 were born in the United Kingdom, three each in Cyprus and Iran, two each in France, Italy, and Pakistan, and one each in Austria, Brazil, Canada, Malta, New Zealand, Roumania, and South Africa. 31 were married and 75 were single, and their average age was 27.9 years (range 18 to 48 ).

Only 37 patients had had no previous venereal or related incident. The remainder had had 63 previous attacks of gonorrhoea, 103 of non-gonococcal urethritis, five of syphilis, four of balanitis, two of yaws, and one each of orchitis, non-specific proctitis, and pediculosis pubis. One patient had previously been treated epidemiologically as a contact of gonorrhoea and eight had sought advice on account of anxiety concerning venereal disease-a total of 189 previous incidents; 86 of these (including 30 attacks of gonorrhoea and 49 of nongonococcal urethritis) had been contracted by the 26 Negro patients, who thus had an average of 3.3 previous incidents compared with 2.3 for the remainder. One Negro patient had had 27 previous incidents including twenty attacks of non-gonococcal urethritis, and one West Indian and another United Kingdom-born person had each had twelve previous incidents.

The discharge had been present before treatment for 1-3 days in 47 patients, for 4-7 days in 33, for 8-14 days in thirteen, for 15-21 days in two, for 22-28 days in six, and for longer than this time in five; 61 patients complained of dysuria.

The disease had apparently been caught from a friend in 55 cases, from a stranger in 34, from the wife in 15, and 
from a man in two cases. The apparent incubation period was 1-3 days in 39, 4-7 days in nineteen, 8-14 days in ten, 15-21 days in nine, 22-28 days in six, and more than 28 days in nine; the incubation period was unknown in fourteen cases.

\section{Diagnosis and Case Management}

Gonorrhoea had been excluded in all cases by examination of a Gram-stained urethral smear, and trichomoniasis by darkfield examination of a wet urethral smear. Routine Wassermann and VDRL tests were performed on sera from all patients, who were then given a bottle containing 25 tablets of $250 \mathrm{mg}$. erythromycin stearate with instructions to take one tablet four times daily for 6 days.

The patients were seen again a week later, when the urethra was examined for discharge, a smear being taken if present, and the urine for haze and threads. It was intended that patients should be seen and examined similarly at approximately 3, 7, and 12 weeks after treatment, at least one examination of the prostatic secretion being made during this time. Re-treatment was undertaken for persistence or recurrence of purulent urethral discharge and for continuation or recurrence of haze or multiple threads in the urine.

\section{Follow-up and Results}

By no means all patients attended at the times requested, but a sufficient time was allowed before assessment so that every patient could have been followed for at least 3 months. The follow-up and results are shown in Table I.

\section{TABLE I}

OVERALL RESULTS OBTAINED IN TREATMENT OF NON-GONOCOCCAL URETHRITIS WITH ERYTHROMYCIN

\begin{tabular}{|c|c|c|c|c|}
\hline \multirow[b]{2}{*}{ Follow-up } & \multirow{2}{*}{$\begin{array}{l}\text { No. } \\
\text { Followed }\end{array}$} & \multicolumn{3}{|c|}{ Result } \\
\hline & & Satisfactory & $\begin{array}{l}\text { Gonococcal } \\
\text { Infection }\end{array}$ & $\begin{array}{l}\text { Recurrence } \\
\text { of NGU }\end{array}$ \\
\hline $\begin{array}{l}0 \\
1-7 \text { days } \\
8-14 \text { days } \\
15-21 \text { days } \\
22-28 \text { days } \\
1-2 \text { mths } \\
2-3 \text { mths }\end{array}$ & $\begin{array}{r}106 \\
92 \\
69 \\
57 \\
42 \\
38 \\
14\end{array}$ & $\begin{array}{r}\overline{17} \\
6 \\
9 \\
2 \\
15 \\
5\end{array}$ & $\frac{\overline{4}}{\frac{1}{1}}$ & $\begin{array}{l}-2 \\
6 \\
5 \\
2 \\
8 \\
3\end{array}$ \\
\hline More & & & & $\begin{array}{l}3 \text { mths total } \\
26\end{array}$ \\
\hline $3 \mathrm{mths}$ & 6 & 4 & - & 2 \\
\hline Total & 92 & 58 & 6 & 28 \\
\hline
\end{tabular}

Thus, of 106 patients treated, 92 were followed and the condition of 58 was satisfactory at the last visit; 26 (28.3 per cent. of those followed) required re-treatment for NGU within three post-treatment months.
Six patients developed gonorrhoea, evident in four cases within 7 days, and it is likely that three of these cases were instances of misdiagnosis and that the gonorrhoea originally present was not suppressed by the dosage of erythromycin used.

No satisfactory criteria exist to distinguish relapse from re-infection apart from admission of further sexual intercourse. Judged purely on this basis, seven of the 26 recurrences noted within 3 months, only one of which occurred before the 21 st day, could have been considered as re-infections, and nineteen (twelve of which occurred during the first 3 weeks) as failures. However, the variable and sometimes prolonged incubation period of nongonococcal urethritis and the great difficulties of demonstrating that a particular woman is the cause of the condition in the male render such a distinction of little value and the author has followed his usual practice in assessing curative agents in this condition by calculating re-treatment rates based on all recurrences occurring within three months of treatment and excluding only those noted after this time.

Results in Immigrants and UK-born Persons

These results, which were similar, are contrasted in Table II.

TABLE II

RESULTS IN IMMIGRANTS AND UNITED KINGDOM-BORN PERSONS

\begin{tabular}{c|c|c|c|c|c|c}
\hline & $\begin{array}{c}\text { No. } \\
\text { Group }\end{array}$ & $\begin{array}{c}\text { No. } \\
\text { Followed }\end{array}$ & $\begin{array}{c}\text { Satis- } \\
\text { factory }\end{array}$ & $\begin{array}{c}\text { Gono- } \\
\text { coccal } \\
\text { Infection }\end{array}$ & $\begin{array}{c}\text { Re-treated for } \\
\text { NSU within } \\
3 \text { mths }\end{array}$ \\
\hline $\begin{array}{c}\text { Immigrants } \\
\begin{array}{c}\text { United } \\
\text { Kingdom- }\end{array}\end{array}$ & 45 & 40 & 25 & 4 & 11 & $\begin{array}{c}\text { Per } \\
\text { cent. }\end{array}$ \\
\hline Total & 106 & 92 & $52 \cdot 5$ \\
\hline
\end{tabular}

* Including the two cases showing re-infection after 3 months.

\section{Results contrasted with Earlier Series}

The results obtained with erythromycin in the present study are contrasted with those of the earlier series undertaken in 1955 in Table III. The findings were very similar.

TABLE III

RESULTS OBTAINED WITH ERYTHROMYCIN IN 1955 AND 1967

\begin{tabular}{|c|c|c|c|c|c|}
\hline \multirow{2}{*}{ Year } & \multirow{2}{*}{$\begin{array}{c}\text { Dosage } \\
\text { (g.) }\end{array}$} & \multirow{2}{*}{$\begin{array}{l}\text { No. } \\
\text { Treated }\end{array}$} & \multirow{2}{*}{$\begin{array}{l}\text { No. } \\
\text { Followed }\end{array}$} & \multicolumn{2}{|c|}{ Re-treated } \\
\hline & & & & No. & Per cent. \\
\hline $\begin{array}{l}1955 \\
1967\end{array}$ & $\begin{array}{l}6 \cdot 0 \\
6 \cdot 25\end{array}$ & $\begin{array}{l}101 \\
106\end{array}$ & $\begin{array}{l}85 \\
92\end{array}$ & $\begin{array}{l}23 \\
26\end{array}$ & $\begin{array}{l}27 \cdot 1 \\
28 \cdot 8\end{array}$ \\
\hline Total & & 207 & 177 & 49 & $27 \cdot 7$ \\
\hline
\end{tabular}




\section{Results contrasted with Those obtained by Other Methods}

The overall results obtained with erythromycin in the two series are compared in Table IV with those achieved under similar conditions using 23 other treatment methods. It will be noted that the re-treatment rates with erythromycin were almost identical with those obtained with streptomycin together with sulphonamides.

TABLE IV

RESULTS OF TREATMENT OF NON-GONOCOCCAL URETHRITIS BY 24 DIFFERENT TREATMENT METHODS

\begin{tabular}{|c|c|c|c|c|c|}
\hline \multirow[b]{2}{*}{ Drug } & \multirow{2}{*}{$\begin{array}{l}\text { Usual } \\
\text { Dosage } \\
\text { (g.) }\end{array}$} & \multirow{2}{*}{ Nreated } & \multirow{2}{*}{$\begin{array}{l}\text { No. } \\
\text { Followed }\end{array}$} & \multicolumn{2}{|c|}{ Re-treated } \\
\hline & & & & No. & $\begin{array}{c}\text { Per } \\
\text { cent. }\end{array}$ \\
\hline $\begin{array}{l}\text { Tetracycline and } \\
\text { oleandomycin } \\
\text { Oxytetracycline } \\
\text { Limecycline }\end{array}$ & $\begin{array}{c}6 \\
5-6 \\
4 \cdot 9\end{array}$ & $\begin{array}{r}106 \\
85 \\
101\end{array}$ & $\begin{array}{l}82 \\
82 \\
65\end{array}$ & $\begin{array}{l}12 \\
13 \\
11\end{array}$ & $\begin{array}{l}14.6 \\
15.9 \\
16.9\end{array}$ \\
\hline $\begin{array}{l}\text { Tetracycline } \\
\text { hydrochloride } \\
\text { Chlortetracycline } \\
\text { Spiramycin } \\
\text { Triacetyloleandomycin }\end{array}$ & $\begin{array}{c}5 \\
10-6 \\
6\end{array}$ & $\begin{array}{l}124 \\
115 \\
134 \\
100\end{array}$ & $\begin{array}{r}108 \\
108 \\
123 \\
85\end{array}$ & $\begin{array}{l}20 \\
20 \\
25 \\
19\end{array}$ & $\begin{array}{l}18 \cdot 5 \\
18 \cdot 5 \\
20 \cdot 3 \\
22 \cdot 4\end{array}$ \\
\hline $\begin{array}{l}\text { Streptomycin + } \\
\text { sulphonamides }\end{array}$ & $\begin{array}{l}1 \cdot 0+ \\
8-12\end{array}$ & 150 & 113 & 31 & $27 \cdot 4$ \\
\hline $\begin{array}{l}\text { Erythromycin } \\
\text { Tetracycline phosphate* } \\
\text { A.B.O.B. } \\
\text { Sulphonamides } \\
\text { Penicillin }\end{array}$ & $\begin{array}{c}6 \\
4 \\
2 \cdot 4 \\
8-28 \\
1-3 \cdot 6\end{array}$ & $\begin{array}{r}207 \\
150 \\
58 \\
215 \\
70\end{array}$ & $\begin{array}{r}177 \\
130 \\
54 \\
195 \\
65\end{array}$ & $\begin{array}{l}49 \\
36 \\
20 \\
73 \\
26\end{array}$ & $\begin{array}{l}27 \cdot 7 \\
27 \cdot 7 \\
37 \cdot 0 \\
37 \cdot 4 \\
40 \cdot 0\end{array}$ \\
\hline & $\begin{array}{l}\text { mega- } \\
\text { units }\end{array}$ & & & & \\
\hline Chloramphenicol & $5-6$ & 39 & 37 & 16 & $40 \cdot 5$ \\
\hline $\begin{array}{l}\text { Spectinomycin }+ \\
\text { sulphonamides }\end{array}$ & $\begin{array}{c}1 \cdot 6+ \\
10\end{array}$ & 42 & 34 & 15 & $44 \cdot 1$ \\
\hline $\begin{array}{l}\text { Streptomycint } \\
\text { Metronidazole } \\
\text { Aminitrozole }\end{array}$ & $\begin{array}{l}1-4 \\
4 \cdot 2 \\
1 \cdot 8-\end{array}$ & $\begin{array}{r}164 \\
70 \\
49\end{array}$ & $\begin{array}{r}141 \\
58 \\
45\end{array}$ & $\begin{array}{l}65 \\
28 \\
22\end{array}$ & $\begin{array}{l}46 \cdot 1 \\
48 \cdot 3 \\
48 \cdot 9\end{array}$ \\
\hline $\begin{array}{l}\text { Spectinomycin } \\
\text { Compound } 17025 \\
\text { Novobiocin } \\
\text { Nalidixic acid } \\
\text { Ampicillin } \\
\text { Placebo }\end{array}$ & $\begin{array}{c}1.6 \\
2 \\
6-12 \\
28 \\
6 \\
\end{array}$ & $\begin{array}{l}30 \\
13 \\
40 \\
10 \\
12 \\
29\end{array}$ & $\begin{array}{r}26 \\
13 \\
36 \\
8 \\
12 \\
22\end{array}$ & $\begin{array}{r}14 \\
7 \\
20 \\
5 \\
8 \\
15\end{array}$ & $\begin{array}{l}53 \cdot 8 \\
53 \cdot 8 \\
55 \cdot 6 \\
62 \cdot 5 \\
66 \cdot 7 \\
68 \cdot 2\end{array}$ \\
\hline Total & 一 & 2113 & 1819 & 569 & $31 \cdot 3$ \\
\hline
\end{tabular}

* With and without $4 \mathrm{mg}$. methyl prednisolone.

+ With and without phenylbutazone.

\section{Summary and Conclusions}

106 patients with uncomplicated non-gonococcal urethritis were treated with erythromycin stearate in a dosage of $6 \cdot 25 \mathrm{~g}$. given over 6 days. The retreatment rate within 3 months was $28 \cdot 3$ per cent. of the 92 patients followed.

No significant difference in results was noted between immigrants and United Kingdom-born persons, and the total re-treatment rate was very similar to that obtained 12 years earlier using $6.0 \mathrm{~g}$. spread over 5 days ( $27 \cdot 1$ per cent.).

A comparison of the combined results of erythromycin therapy with those of 23 other methods indicates that they are almost identical with those obtained using the regime of single injections of $1 \mathrm{~g}$. streptomycin together with a course of sulphonamides, a method which has been much used in the treatment of this condition in the past.

Thanks are due to Abbott Laboratories Ltd. for kindly providing the erythromycin used in this study.

\section{REFERENCES}

Csonka, G. W., Williams, R. E. O., and Corse, J. (1966). Lancet, 1, 1292.

Dunlop, E. M. C., Harper, I. A., Al Hussaini, M. K., Garland, J. A., Treharne, J. D., Wright, D. J. M., and Jones, B. R. (1966). Brit. F. vener. Dis., 42, 77. Furness, G., and Csonka, G. W. (1966). Ibid., 42, 185. Shepard, M. C. (1960). Ann. N.Y. Acad. Sci., 79, 397. -, Lunceford, C. D., and Baker, R. L. (1966). Brit. $\mathscr{F}$. vener. Dis., 42, 21.

Willcox, R. R. (1954). Lancet, 2, 684.

- (1955a). Antibiotic Med., 1, 139.

- (1955b). Brit. F. vener. Dis., 31, 186.

- (1955c). Postgrad. med. F., 31, 500.

\section{L'érythromycine dans le traitement de l'urétrite non-gonococcique \\ Résumé}

106 patients atteints d'urétrite non-gonococcique sans complications ont été traités avec le stéarate d'érythromycine à la posologie de 6,25 grammes données pendant une période de six jours. Des 92 patients suivis pendant trois mois 28,3 pour cent ont eu besoin d'un second traitement.

Aucune différence significative dans les résultats n'a été noteie entre les immigrants et les personnes nées au Royaume-Uni et le taux total d'un second traitement était très similaire $(27,1$ pour cent) à celui obtenu 12 ans auparavant quand 6,0 grammes avaient été donnés pendant cinq jours.

Une comparaison entre les résultats de la thérapie à l'érythromycine et ceux de 23 autres méthodes indique qu'ils sont presque identiques à ceux obtenus en se servant d'une seule injection de streptomycine combinée à un traitement par les sulfamidés, méthode qui a été très employée dans le passé pour le traitement de cette affection. 